\title{
PENERAPAN UKIR TEMBAGA PADA BODY BECAK
}

\author{
Budi Hartono \\ (Institut Seni Indonesia Yogyakarta, baworbudi@gmail.com \\ 081227744493) \\ Gandar Setiawan \\ (Institut Seni Indonesia Yogyakarta, gandarsetiawan@gmail.com \\ 087839823032)
}

\begin{abstract}
The body of a typical becak in Yogyakarta, especially the becak section, is usually decorated with paintings of scenery or puppet figures, and so on. The existence of becak is gradually eroded by technological advances. Becak now look less attractive because some drivers change motorcycle engines to drive becak. The characteristic of becak as a vehicle that is used by human power, began to wear off. As a result, many becak in Yogyakarta are stuck in used goods collectors. Such conditions become a challenge in itself to revitalize it. The purpose of this research is to make innovations with copper media as an application of artistic appearance of rickshaw bodies, especially in the fender section by using carving techniques. The fender part is an important part of the rickshaw as a traditional vehicle, this part gives a strategic look because it is easy to see and its attractive shape makes it easier to respond to be more artistic as a becak decoration. This research method uses practice based research, while the result of this study is copper carving applied to the fender becak Copper carving technique has a special value for everyone who sees it. Copper has a distinctive and specific color as a metal material for each accompanying metal element.
\end{abstract}

Keywords: copper carving, body cover, becak

\section{ABSTRAK}

Body becak khas Yogyakarta, terutama bagian slebor, biasanya dihiasi dengan lukisan pemandangan ataupun tokoh pewayangan, dan sebagainya. Keberadaan becak lambat laun tergerus oleh kemajuan teknologi. Penampilan becak sekarang kurang menarik karena sebagian pengemudi mengganti mesin motor untuk menggerakkan becak. Ciri khas becak sebagai kendaraan yang dikayuh memakai tenaga manusia, mulai luntur. Akibatnya, banyak becak di Yogyakarta teronggok di pengepul barang bekas. Kondisi demikian menjadi tantangan tersendiri untuk merevitalisasinya. Tujuan penelitian ini adalah membuat inovasi dengan media tembaga sebagai aplikasi tampilan artistik body becak, terutama di bagian sepatbor/spakbor dengan cara menggunakan teknik ukir. Bagian slebor adalah bagian penting dari becak sebagai kendaraan tradisional. Bagian ini memberikan tampilan yang strategis karena mudah dilihat dan bentuknya yang menarik, sehingga memudahkan untuk direspon menjadi lebih artistik sebagai dekorasi becak. Metode penelitian ini menggunakan metode practice based research, sedangkan hasil penelitian ini berupa ukiran tembaga yang diterapkan pada bagian spakbor becak. Teknik ukir berbahan tembaga mempunyai nilai spesial bagi setiap orang yang melihatnya. Tembaga memiliki warna yang khas dan spesifik sebagai material logam untuk setiap elemen logam yang menyertainya.

Kata Kunci : ukir tembaga, penutup body, becak 


\section{PENDAHULUAN}

Setiap negara mempunyai kendaraan khasnya. Thailand terkenal dengan tuk-tuk, yaitu kendaraan beroda tiga. Kendaraan ini diekspor dari Jepang ke Thailand sejak tahun 1934. Tuk-tuk menjadi alat transportasi yang beroperasi di area perkotaan, seperti Bangkok dan lainnya. Tuk-tuk bisa ditumpangi lima orang walau berdesakan. Biasanya, setiap tuk-tuk mempunyai hiasan yang cukup ramai. Pengendara tuk-tuk menghias kendaraan mereka sesuai selera mereka. Di dalam tuk-tuk biasanya ada foto Raja Thailand serta penerapan warna-warna mencolok yang menjadi ciri khasnya.

Model kendaraan tradisional yang hampir sama dengan mesin ataupun digerakkan dengan tenaga manusia juga bisa ditemui di Filipina, El-Salvador, India, China, Jepang, Portugal, Columbia, Kamboja, hingga Ethiopia. Akan tetapi, mesin tuk-tuk termasuk lebih halus apabila dibandingkan dengan bajaj yang ada di Indonesia. Di Jepang, kita akan menemui Jinrikisha. Kata Jin berarti manusia, sedang Riki berarti kekuatan atau tenaga, dan Sha berarti kendaraan. Jadi, Jinrikisha bisa diartikan kendaraan yang ditarik dengan tenaga manusia. Meskipun saat ini tidak banyak ditemukan lagi, Jinrikisha menjadi alat transportasi utama di Jepang hingga sekitar tahun 1940-an.

Seiring arus modernisasi transportasi, becak yang lamban dan membutuhkan tenaga manusia untuk mengayuh, semakin terpinggirkan secara perlahan. Becak sekarang semakin sedikit digunakan oleh masyarakat karena alasan segi kepraktisan, waktu, dan sebagainya. Untuk menyiasatinya, banyak sopir becak yang kemudian mengubah becaknya menjadi becak bermotor (sering disebut sebagai bentor). Becak khas Yogyakarta, terutama pada bagian slebor, biasanya dihiasi dengan lukisan pemandangan ataupun tokoh pewayangan, dan sebagainya.
Keberadaan becak lambat laun tergerus oleh kemajuan teknologi. Penampilan becak sekarang kurang menarik karena sebagian pengemudi menggantinya dengan mesin motor untuk menggerakkan becak, sehingga ciri khas becak sebagai kendaraan yang dikayuh memakai tenaga menusia, mulai luntur. Akibatnya, banyak becak di Yogyakarta teronggok di pengepul barang bekas. Kondisi demikian menjadi tantangan tersendiri bagi penulis. Tujuan penelitian ini adalah membuat inovasi pada media tembaga sebagai tampilan artistik penutup body becak terutama di bagian slebor dengan cara diukir. Efek dekorasi yang berdimensi ditimbulkan dari teknik ukir merupakan ciri khas unik material logam, karena menampilkan tekstur dan warna klasik pada permukaan logam tembaga yang indah.

Teknik ukir yang biasa dikenal pada ukir perak, tembaga, kuningan, ataupun aluminium ialah wudulan, yakni teknik membuat permukaan logam berdimensi sesuai dengan desain yang akan dibuat. Permukaan logam yang tadinya flat, akan berdimensi dengan variasi menyesuaikan tinggi-rendahnya rancangan karya. Inilah yang membedakan dengan teknik sebelumnya pada penutup body (slebor) becak, yaitu dengan cara dilukis.

Inovasi yang akan dilakukan yaitu pada pemilihan gaya desain dengan memadukan gaya khas becak Yogyakarta dengan unsur ornamen pada karya body, khususnya bagian slebor. Era 4.0 sekarang teknologi berkembang di segala bidang ilmu, termasuk industri kreatif. Zaman bergerak begitu cepat, begitupun perubahan yang terjadi dalam banyak hal, kerajinan, desain, inovasi produk, dan lain sebagainya. Demikian pula perkembangan industri furnitur ataupun home décor sangat menggembirakan, terutama yang berbahan logam. Permintaan produk home décor berbahan logam di Benua Amerika, Eropa, dan Afrika cukup pesat. Permintaan produk home décor juga dapat dilihat dengan maraknya 
penjualan secara online. Hal ini tampak pada beberapa produk lokal dengan pabrikan tertentu, misalnya yang ada di daerah Kasongan dan sekitarnya. Hal yang perlu diperhatikan oleh para produsen adalah diferensiasi produk dan penggayaan desain yang variatif. Kolaborasi antara industri kreatif dengan pembuatan pada penutup body becak dirasakan akan menarik dan mungkin menghasilkan produk baru yang memiliki karakter khas.

Tantangan inovasi penggunaan bahan logam ini adalah jenis bahan dan gaya desain yang variatif untuk digunakan pada produk home décor. Metode yang digunakan untuk penelitian ini adalah metode practice based research untuk perancangan produk home décor berbahan tembaga dengan teknik ukir.

Tujuan penelitian ini adalah menggunakan logam tembaga dengan teknik ukir wudulan, serta pengayaan desain yang pas untuk penutup body becak sebagai produk home décor. Penelitian ini mampu menciptakan penggayaan desain pada logam tembaga untuk meningkatkan daya saing produk di tengah kompetisi pasar yang ketat dan semakin beragam jenisnya.

Manfaat yang diperoleh dari penelitian ini adalah daya tarik produk untuk memperluas target pasar. Daya tarik produk akan diperoleh apabila memiliki karakteristik yang kuat dan desain yang khas sebagai elemen home décor. Sebagai elemen estetis akan banyak variasi bahan ataupun desain home décor yang ada di pasaran, baik dalam negeri maupun mancanegara.

Salah satu sentra pembuatan elemen home decor terbesar di Indonesia terletak di provinsi Jawa Tengah, yaitu Kabupaten Boyolali. Perkembangan industri kerajinan logam di Boyolali dari tahun ke tahun cukup signifikan, terbukti sentra industri ini banyak diekspor ke luar negeri, apalagi setelah dikunjungi Presiden Jokowi. Industri kerajinan logam di Boyolali banyak menghasilkan produk ukiran logam tembaga maupun logam non-ferro lainnya. Selama ini produk ukir di Boyolali belum menyentuh pada pengayaan desain yang merespons penutup body becak sebagai produk home décor. Sementara itu, penutup body yang biasa ditemui menggunakan teknik lukisan yang penampilannya berbeda apabila dengan teknik ukir. Terkait dengan fenomena tersebut, dapat dirangkai suatu hubungan yang saling menguntungkan antara inovasi material dan teknik ukir pada body cover becak dengan peningkatan daya saing produk. Jika terjadi koneksi antara kebutuhan dan ketersediaan, langkah inovasi dalam perancangan produk home décor akan memberikan nilai tambah.

Berkaitan dengan pernyataan dan penjelasan tersebut di atas, tulisan ini memaparkan rancangan produk penutup body becak Yogyakarta sebagai elemen estetis interior. Adapun yang dimaksud dengan penutup body di sini adalah bagian slebor becak dengan menggunakan teknik ukir pada logam tembaga sebagai mediumnya, dan ilustrasi ragam hias menyesuaikan dengan ciri khas Yogyakarta sebagai elemen artistik desainnya.

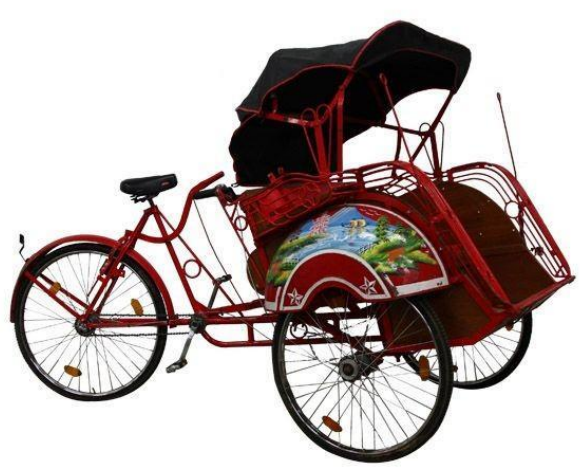

Gambar 1. Becak Yogyakarta

\section{METODE}

Penelitian, khususnya penelitian seni dan desain, biasanya mempertanyakan tiga hal, yaitu mengidentifikasi untuk menjawab definisi, memahami konteks secara lebih luas, dan mengembangkan metode serta mengambil informasi yang relevan untuk menjawab pertanyaan dalam penelitian, serta 
mengevaluasi dan menganalisisnya (Gray dan Malins, 2004:12). Menurut Miles dan Hubermas (dalam Carol Gray dan Julian Malins, 2004: 144), terdapat tiga aktivitas kunci dalam menganalisis, yaitu mereduksi data, mendisplay data, dan mengambil konklusi. Dalam penelitian seni dan desain sangat diperlukan fleksibilitas untuk menganalisis suatu data. Sebaliknya, dalam menganalisis data digunakan beberapa alat yang dapat mempermudah proses tersebut.

Dikutip dari Candy, L. \& Edmonds, E. (dalam Centaury Harjani, 2019: C2-6), PracticeBased Research adalah suatu metode penelitian untuk memperoleh suatu pengetahuan baru melalui praktik dan hasil praktik yang dilakukan dalam penelitian. Penelitian dan praktik pada metode ini saling bergantung dan melengkapi satu sama lain. Candy (2006) menjelaskan empat elemen kunci secara singkat pada pengantar publikasinya yang berjudul PracticeBased Research: A Guide, yaitu:

a. Permasalahan (The Problem)

Permasalahan adalah sebuah pernyataan sederhana dari pertanyaan dan masalah yang dibahas dalam penelitian ini. Dalam hal ini penulis mendapatkan permasalahan di bagian slebor becak. Penulis mewujudkan aplikasi dengan menerapkan ilustrasinya. Maksudnya adalah bagian slebor becak merupakan bagian yang menarik untuk direspons.

b. Konteks (The Contex)

Bagaimana karya yang telah dilakukan yang memunculkan pertanyaan dan makna seperti apa? (permasalahan apa yang dibahas). Penulis menemukan solusi untuk memakai ornamen khas Yogyakarta ataupun ciri khas Yogyakarta sebagai kota seni dan budaya.

c. Metode (The Method)

Pendekatan untuk memecahkan masalah (eksperimental, berbasis praktik, analitik) dijelaskan dalam bagian ini. Penulis melakukan dan mengumpulkan sketsa untuk menemukan ilustrasi yang pas. Kemudian penulis memodifikasi sketsa dengan cara diperbesar. Langkah selanjutnya ialah menempelkan pada plat tembaga $0,8 \mathrm{~mm}$.

d. Hasil (The Outcomes)

Hasil yang diperoleh adalah penerapan ilustrasi pada body slebor dengan teknik ukir logam. Tekniknya menggabungkan plat tembaga yang sudah diukir ditempelkan ke dalam slebor yang berbahan plat besi dengan cara disekrup. Konstruksi ini dibuat dengan perhitungan yang matang, sehingga di samping kuat, kerapian konstruksi sangat diperhitungkan. Ilustrasi ukir logam berbahan plat tembaga secara visual memiliki kelebihan karena dimensi tekstur yang menonjol dan memiliki ketebalan. Dari segi material, logam tembaga memiliki kelebihan yaitu anti karat dan lebih tahan cuaca dibandingkan dengan logam ferro.

Practice-by Research yang dilakukan Candy L dan Edmonds E (2018) merupakan penelitian yang menghasilkan suatu pengetahuan baru dari yang dihasilkan saat praktik ataupun hasil dari praktik tersebut. Pada proses praktik yang melibatkan kreativitas tidak hanya berfokus pada menciptakan suatu karya, tetapi cara proses pembuatan tersebutlah yang mengarah ke transformasi ide baru dan mengarah ke pekerjaan baru. Seperti halnya saat penulis mengerjakan penelitian, untuk menciptakan sebuah karya, penulis harus melakukan beberapa trial and error untuk mencapai hal yang diinginkan.

Pada proses pembuatan karya inilah yang menghasilkan suatu pengetahuan baru, baik itu kegagalan saat berproses maupun menemukan jalan pintas baru saat berproses. Hal inilah yang perlu dicapai saat pembuatan karya agar kegagalan yang terjadi tidak akan 
terulang ke depannya dan pada proses yang baru harus dikembangkan. Pendekatan menggunakan practice-based research merupakan metode penciptaan yang sesuai dengan penelitian terapan kali ini. Metode berbasis praktik memiliki pendekatan yang unik, karena praktik itu sendiri merupakan bagian dari penelitiannya. Alternatif praktik dianggap sebagai sebuah penelitian bila memiliki jawaban yang positif terhadap lima pertanyaan berikut:

1. Apakah aktivitas praktlk yang dilakukan merupakan penyelidikan atau eksplorasi yang sasarannya adalah menemukan sebuah pengetahuan?

2. Apakah kegiatan praktik kerja studio dilakukan secara sistematis?

4. Apakah data dan informasi terkait proses kerja yang dilakukan dikumpulkan dan ditampilkan secara eksplisit?

5. Catatan yang dibuat terkait dengan proses pengerjaan karya dibuat secara transparan tidak ditutup-tutupi?

6. Apakah semua hasil kegiatan dari proses praktlk yang dikerjakan divalidasi dengan cara yang benar?

Maka, apabila sebagian besar pertanyaan tersebut dijawab dengan jawaban positif, praktik berbasis penelitian yang dilakukan ini telah memenuhi kaidah keilmuan sebuah penelitian. Adapun penggunaan metode practice-based research yang penulis lakukan dalam bentuk yang disederhanakan, disesuaikan dengan kebutuhan praktik kerja yang telah dilaksanakan.

Dalam penelitian kali ini langkahlangkah dalam menerapkan metode practice based research ini dapat dilihat dalam bagan sebagai berikut:

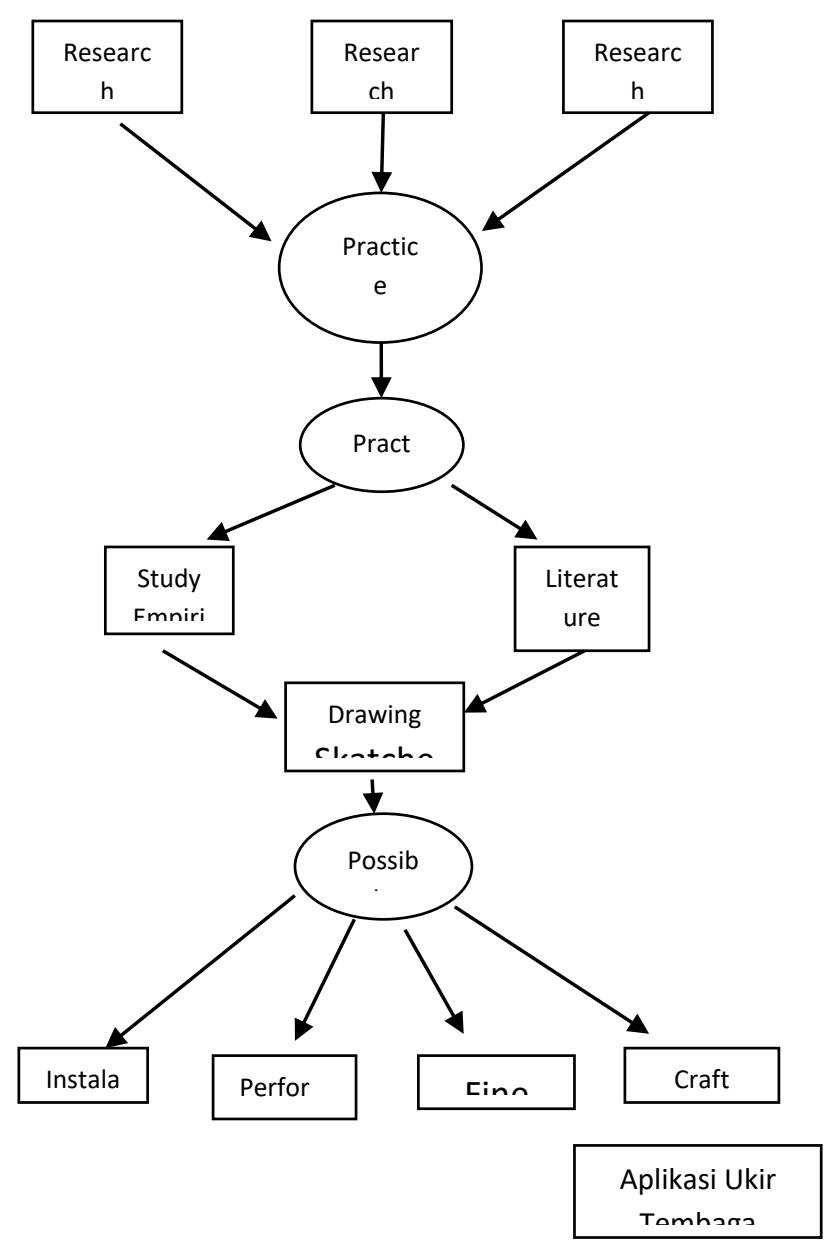


Gambar 2. BaganLangkah-Langkah Penelitian berdasarkan Metode Practice-Based Research

Berdasarkan uraian bagan tersebut, dapat dijelaskan bahwa penciptaan yang berbasis penelitian tentunya harus diawali dengan studi mengenai pokok persoalan dan materi yang diambil, seperti ide, konsep, tema, bentuk, teknik, bahan, dan penampilan. Segala materi ini diulas secara mendalam agar dapat dipahami sehingga telah menguasai dan menjiwai objek tersebut.

Dalam penciptaan karya ini hal yang sangat penting untuk ditelusuri secara mendalam, yaitu konsep penciptaan itu sendiri, karena pada bagian ini penggunaan konsep adalah bagian utama penciptaan. Diawali merumuskan berbagai pertanyaan. Selain studi empirik, studi penelitian juga dapat dilakukan dengan studi pustaka dan pengamatan langsung terhadap objek yang diteliti.

\section{HASIL DAN PEMBAHASAN}

Hasil perancangan seni penerapan ornamen pada slebor becak selama kurang lebih enam bulan ini dilakukan melalui berbagai tahapan perancangan agar terarah dan sistematis. Tentu diharapkan menghasilkan rancangan yang berkualitas dan memberikan kekayaan desain, metode Practice-Based Research menjadi tahapan proses atau acuan penulis untuk menyelesaikan penelitian ini. Practice-Based research suatu metode penelitian untuk memperoleh suatu pengetahuan baru melalui praktik dan hasil praktik yang dilakukan dalam penelitian dan saling bergantung melengkapi satu sama lain.

Perkembangan home décor atau wall decor sebagai produk interior di Yogyakarta cukup pesat. Seiring perkembangan tren home décor dan respons masyarakat yang positif, kini materialnya pun beraneka ragam jenisnya, seperti kayu, akrilik, batu, dan pemanfaatan barang bekas, seperti slebor becak yang dilukis dengan cat akrilik atau cat minyak. Dalam penelitian ini, penulis memanfaatkan slebor becak sebagai material pendukung penciptaan home décor, dipadu dengan plat tembaga yang diukir ornamen khas Yogyakarta sebagai tujuan penelitian.

Gambar di bawah ini adalah motif batik burung garuda sebagai inspirasi penciptaan ukiran tembaga sebagai elemen estetis pada spakbor becak, selanjutnya akan dijelaskan singkat tentang motif garuda tersebut :

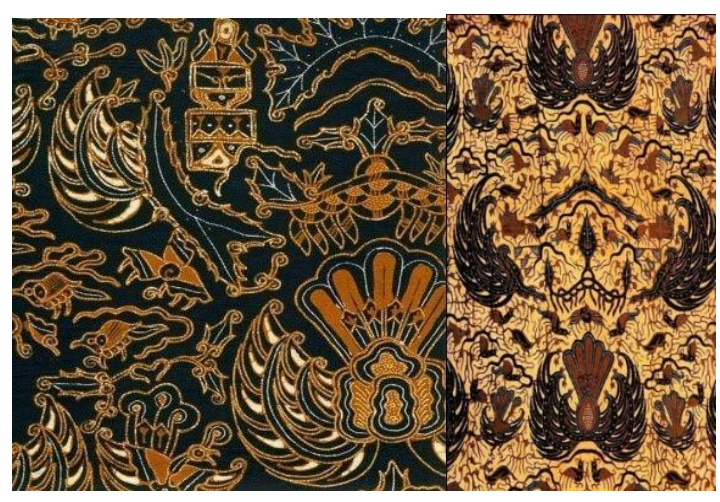

Gambar 3. Motif Burung Garuda atau Gurdha

Gurdha berasal dari kata garuda. Seperti diketahui, garuda merupakan burung besar. Dalam pandangan masyarakat Jawa, burung garuda mempunyai kedudukan yang sangat penting. Bentuk motif gurdha ini terdiri atas dua buah sayap (Iar) dan di tengahnya terdapat badan dan ekor. Motif batik gurdha ini juga tidak lepas dari kepercayaan masa lalu. Garuda merupakan tunggangan Batara Wisnu yang dikenal sebagai Dewa Matahari. Garuda menjadi tunggangan Batara Wisnu dan dijadikan sebagai lambang matahari. Oleh masyarakat Jawa, garuda selain sebagai simbol kehidupan juga sebagai simbol kejantanan.

Teknik penciptaan karya penulis memakai ukir logam tembaga sebagai pembeda dengan teknik yang lain. Ukir logam memiliki ciri khas tekstur yang indah apabila dipadukan dengan unsur ragam hias daerah yang kental akan makna simbolik. Keanekaragaman simbol Yogyakarta menjadi penanda yang kuat dengan 
karakter masyarakat Yogyakarta yang santun penuh kearifan tradisi. Ragam hias sebagai penguat visual ukiran slebor becak akan memberikan ingatan makna bahwa Kota Yogyakarta adalah daerah yang menjaga tradisinya tetap hidup dan menghiasi di setiap ruang kota.
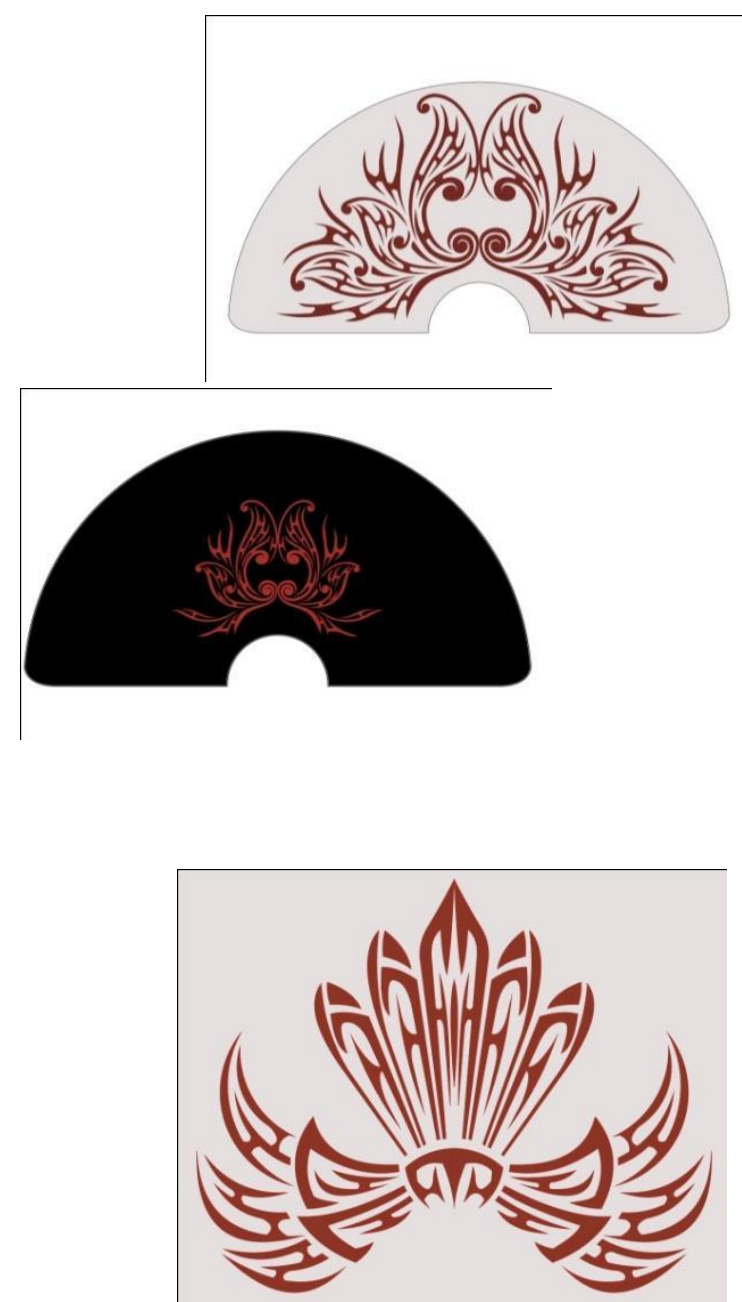

Gambar 4. Sketsa Desain yang sudah Dimodifikasi

Penulis memilih motif batik Garuda atau Gurdha, yaitu melambangkan burung yang suci. Bentuk motif gurdha ini terdiri atas dua buah sayap (lar) dan ditengah-tengahnya terdapat badan dan ekor. Menurut masyarakat Yogyakarta burung ini dianggap sebagai binatang yang suci. Garuda sebagai elemen ragam hias yang dipilih penulis dikembangkan lebih sederhana karena pertimbangan teknik yang berbeda apabila diwujudkan ke dalam media logam tembaga. Penyederhanaan dan aplikasi triball sebagai penguat ornamen memiliki tampilan yang kuat yang berasal dari kesan guratan pahat logam dengan garis-garis yang tegas dan tajam.

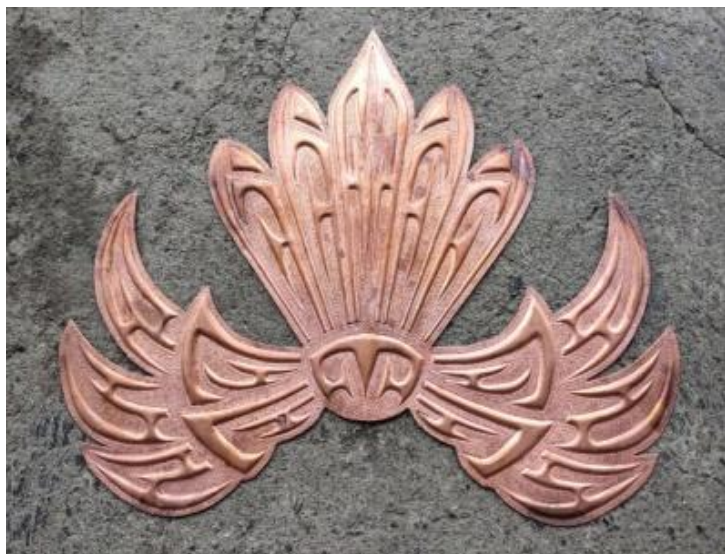

Gambar 5. Sketsa Desain yang sudah Diukir ke Tembaga

Material tembaga memperkuat visual gurdha sebagai ragam hias klasik batik Yogyakarta sebagai penguat home décor kekinian. Maksudnya, ada nilai kreatif pada penerapan motif Garuda dan motif triball maupun pemanfaatan tembaga sebagai material pendukung karya. Pembuatan prototipe ini disesuaikan dengan slebor becak yang memiliki bentuk lengkung hampir setengah lingkaran. Bagian cembung pada slebor becak disesuaikan dengan bentuk motif garuda yang mengikuti lengkung slebor, meskipun sebenarnya prototipe ini bisa juga tanpa menampilkan slebor becaknya. Artinya, ukiran tembaga ini bisa tampil terpisah dan berdiri sendiri semisal di dinding, ataupun dengan material yang lain, seperti kayu dan sebagainya. 


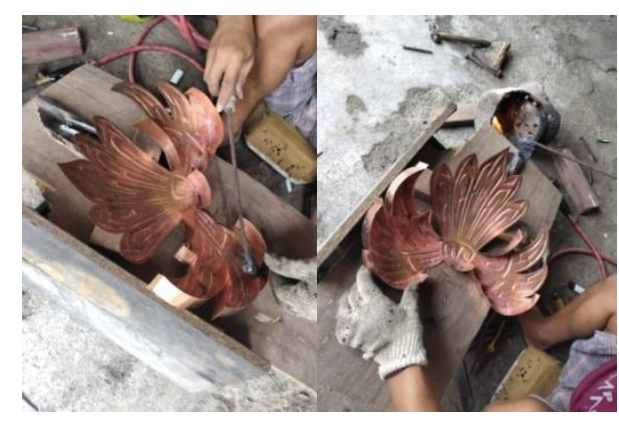

Gambar 6. Proses Pemberian Ketebalan Karya
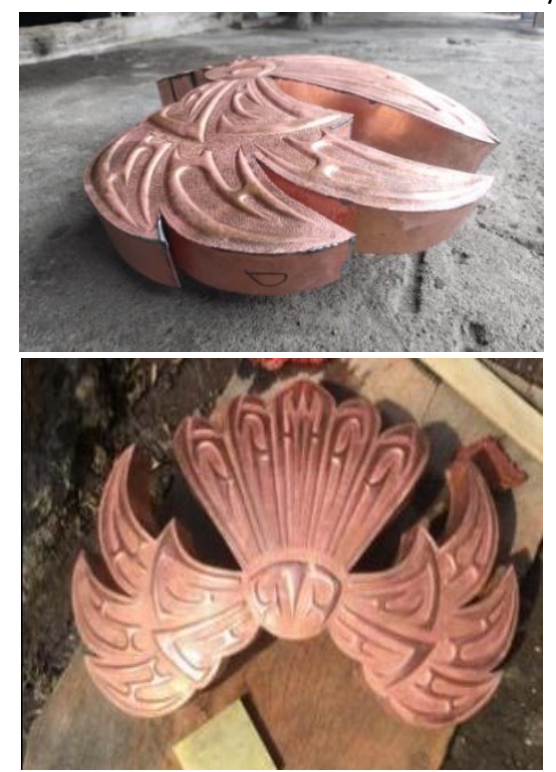

Gambar 7. Karya setelah diberi ketebalan dengan teknik patri.

Selanjutnya, tahapan hasil yang dicapai tersebut sebagai berikut: Penulis memilih slebor becak khas becak Yogyakarta karena bentuk yang khas dan spesifik, memiliki material lebih kokoh dibandingkan bentuk slebor khas daerah kota lainnya. Sedangkan untuk proses desainnya tidak terlepas dari tren desain yang sedang berkembang saat ini, yaitu mengangkat ciri khas khususnya ornamen Yogyakarta.

Data yang dilakukan, yaitu mengumpulkan referensi berupa tren desain yang ada pada saat ini. Pada tahap pembuatan model menggunakan material plat tembaga dengan tebal $0,8 \mathrm{~mm}$. Alasan pemilihan material tembaga karena mudah dibentuk dan mempunyai sifat yang plastis dibandingkan logam kuningan dan aluminium.
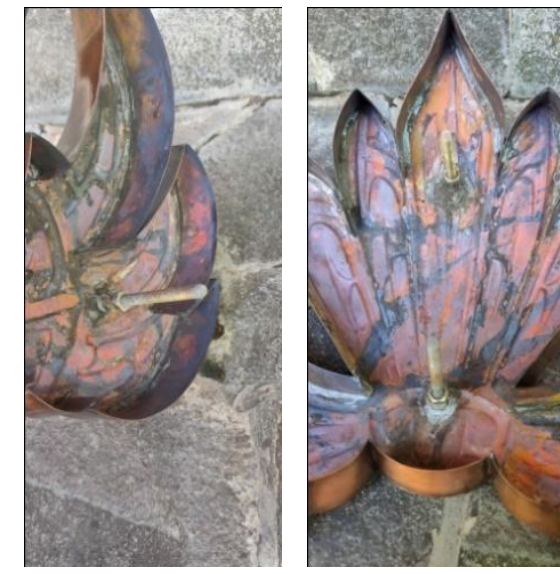

Gambar 8. Konstruksi Karya untuk Memasang Karya

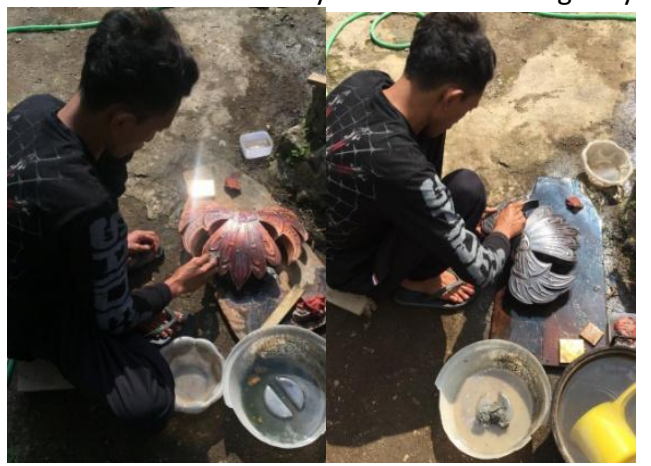

Gambar 8. Finishing karya dengan Penghitam Logam (SN)
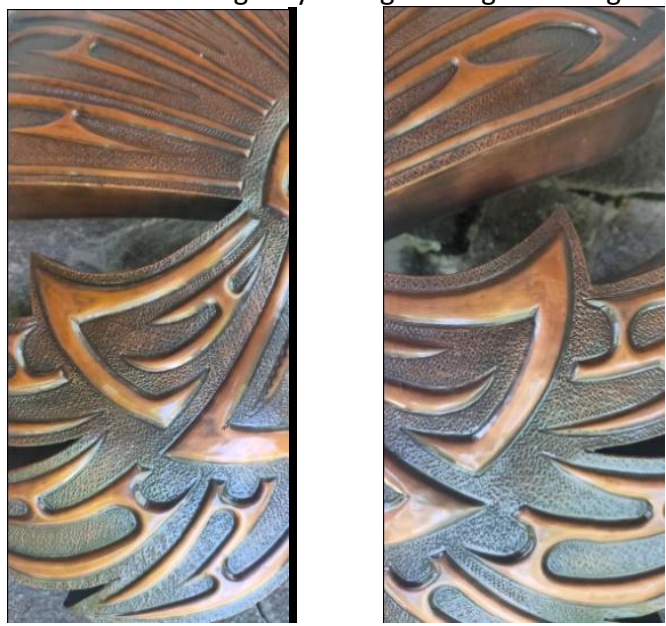

Gambar 9. Detail Ukiran

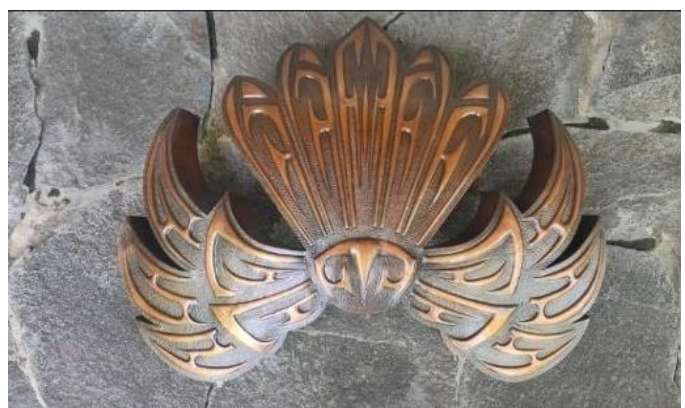

Gambar 10. Karya 
Teknik pengerjaan yang digunakan dalam penciptaan karya ini adalah sebagai berikut:

1. Teknik potong, yaitu suatu teknik memotong logam berupa plat logam, kawat, pipa. Alat potong yang digunakan adalah gergaji tangan dan gunting logam.

2. Teknik pahat, yaitu teknik yang bersifat tradisional karena hasil pekerjaannya mengandalkan keahlian dan keterampilan teknik, yaitu teknik rancapan, wudulan, endak-endakan.

3. Finishing memakai penghitam tembaga, karya yang sudah melalui tahap ukir dan pemberian ketebalan dengan cara dipatri kemudian direndam dengan obat penghitam. Kemudian didiamkan kurang lebih sepuluh menit lalu diangkat dan dibersihkan, cuci dengan air bersih kemudian dikeringkan lalu dipoles dengan pengilap logam pada bagian-bagian yang diinginkan. Selanjutnya disemprot dengan pelapis logam (coating) supaya awet kilapnya dengan tiga kali semprot, didiamkan sekitar sepuluh menit dalam menyemprot, diulangi kembali sampai tiga kali untuk mendapatkan hasil yang bagus.

4. Teknik patri lunak yaitu teknik menyambung dengan menggunakan timah sebagai media untuk menyambung permukaan logam tembaga satu dengan lainnya. Teknik patri lunak merupakan teknik penyambungan logam yang ada di seni kriya logam. Dinamakan patri lunak karena teknik penyambungan karya ini menggunakan suhu rendah.

\section{PENUTUP}

Dari pernyataan dan tulisan yang sudah dikemukakan oleh penulis dapat diambil simpulan antara lain:

1. Ragam hias yang terdapat pada seni batik banyak dijadikan sumber inspirasi bagi para kreator seni. Flora maupun fauna merupakan ragam hias, motif, ilustrasi, yang tergambar indah di setiap lembar kain. Yogyakarta memiliki beragam motif batik, di antaranya motif garuda atau gurdha. Penciptaan karya penelitian terapan ini menggunakan motif garuda sebagai acuan penulis, sebagai karya kreatif atau pengembangan perpaduan dengan motif triball. Bahwa penciptaan produk kreatif tidak sekedar mengulang gambar, motif, yang sudah ada. Penulis dituntut inovatif menggagas ide ataupun mewujudkannya dalam sebuah karya yang memiliki nilai tawar dan kualitas visual setelah karya tersebut dieksekusi.

2. Produk home décor dengan merespons slebor becak sudah ada dan bukan merupakan barang baru. Biasanya slebor becak dilukis dengan gaya lukisan vintage, industrial maupun dekoratif. Saat ini perkembangan gaya desain cukup beraneka macam, sehingga masing-masing gaya tersebut memiliki pasar dan pencintanya. Namun kreativitas dan variasi untuk penciptaan dan pengayaan desain, material, perlu dikembangkan seiring dengan tren dan selera pasar yang mengikutinya. Pemilihan material tembaga menambah alternatif pemilihan material home décor, plat tembaga identik dengan bahan untuk pembuatan ukiran logam. Copper zinc atau plat tembaga jenis logam yang mudah untuk diproses menjadi karya kriya, pemilihan material tembaga memudahkan penulis untuk mewujudkan karya karena tingkat lenturnya berbeda dengan jenis logam lainnya.

3. Konstruksi adalah salah satu bagian terpenting dalam men-display atau memasang karya, hal ini berhubungan dengan penampilan karya apabila terpasang. Konsep dan konstruksi 
display/pemasangan karya yang benar sangat memengaruhi karya itu dari segi kualitasnya. Penting untuk diperhatikan dalam memilih dan menentukan cara yang tepat dalam memasang baut, menyambung logam, memilih letak lobang gantungan pada karya yang tidak simetris, misalnya. Cara ini terlihat sederhana namun hanya dalam pengalaman trial and error biasanya kita menemuinya.

\section{Ucapan Terima Kasih}

Penulis mengucapkan terimakasih dan penghargaan yang sebesar-besarnya kepada semua pihak yang telah membantu lancarnya penelitian terapan ini :

1. Kementrian Pendidikan dan Kebudayaan ;

2. Institut Seni Indonesia Yogyakarta;

3. LPPM Institut Seni Yogyakarta;

4. Dr. Djunaedi, S.Kar., M.Hum.;

5. Dr. Yulriawan Dafri, S.Sn., M.Hum.

\section{Daftar Pustaka}

Candy, L., Edmonds, E. 2018. "Practice-Based Research in the Creative Arts: Foundations and Futures from the Front Line". Leonardo Journal Vol 51 Issue 01, February, p.63-69. Massachusetts: MIT Press.

Hartono, Budi . 2018. "Perancangan Perhiasan Berbahan Pewter" dalam jurnal Corak : Jurnal Seni Kriya Vol. 7 No. 2 Desember 2018.
Hendriyana, Husen. 2018. Metodologi Penelitian Penciptaan Karya. Bandung: Sunan Ambu Press.

Lawson, Bryan.2007. Bagaimana Cara Berpikir Desainer (How Design Think) Yogyakarta: Jalasutra.

Palgunadi, Bram. 2007. Desain Produk I: Desain, Desainer, dan Proyek Desain. Bandung: Penerbit ITB.

Papanek, Victor. 1973. Design for the Real World. Toronto/New York/London: Bantam Books.

Sumartono. 2017. Metodologi Penelitian Kualitatif. Jakarta: Universitas Trisakti.

Untracht, Oppi. 1968. Metal Techniques for Craftmen, A Basic Manual for Craftmen on the Methods of forming and Decorating Metals. New York10103, Douleday.

https://www.batik.or.id

https://www.ejoural.undiksha.ac.id

https://www.journal.binus.ac.id

http://www.winotosastro.com 